\title{
A HŐ- ÉS FELÜLETKEZELŐ SZAKCSOPORT OKTATÁSI-KUTATÁSI TEVÉKENYSÉGE
}

\author{
Kocsisné Baán Mária \\ ny. egyetemi docens, Miskolci Egyetem, Anyagszerkezettani és Anyagtechnológiai Intézet \\ 3515 Miskolc, Miskolc-Egyetemváros, e-mail: m.kocsis.baan@uni-miskolc.hu \\ Cserjésné Sutyák Ágnes \\ mesteroktató, Miskolci Egyetem, Anyagszerkezettani és Anyagtechnológiai Intézet \\ 3515 Miskolc, Miskolc-Egyetemváros, e-mail: mechsagi@uni-miskolc.hu

\section{Frigyik Gábor} \\ ny. egyetemi docens, Miskolci Egyetem, Anyagszerkezettani és Anyagtechnológiai Intézet \\ 3515 Miskolc, Miskolc-Egyetemváros, e-mail: metfga@uni-miskolc.hu
}

\section{Kuzsella László}

egyetemi docens, Miskolci Egyetem, Anyagszerkezettani és Anyagtechnológiai Intézet 3515 Miskolc, Miskolc-Egyetemváros, e-mail: kuzsella@uni-miskolc.hu

\begin{abstract}
Absztrakt
A Miskolci Egyetem Gépészmérnöki és Informatikai Karának Anyagszerkezettani és Anyagtechnológiai Intézetében - a jogelöd Mechanikai Technológiai Tanszék szakmai tevékenységének töretlen folytatásaként - a hökezelés területén több évtizedes, széles körüen elismert oktatási és kutatási, technológia fejlesztési tevékenység folyik. A Tanszék fennállásának 60 éves jubileuma alkalmából publikált összefoglalónkban [1] részletesen bemutattuk a megelözö évtizedek eredményeit, a következö idöszak legfontosabb feladatául pedig a generációváltás elökészitését és megvalósitását tüztük ki, mind személyi, mind technológiai vonatkozásban. Jelen összefoglalónkban így az azóta eltelt tíz év szakmai tevékenységét kivánjuk részletezni, hangsúlyt helyezve azokra az infrastrukturális fejlesztésekre és új $K+F$ témakörökre, amelyek az emlitett generációváltás szempontjából fontos szerepet játszottak.
\end{abstract}

Kulcsszavak: Miskolci Egyetem, hökezelés, felületkezelés

\begin{abstract}
The Institute of Materials Science and Technology at the Faculty of Mechanical Engineering and Informatics belonging to University of Miskolc has been conducting widely appreciated educational, research and technology development activities in the field of heat treatment for several decades. This is the consistent continuation of the professional job / work done by the Department of Mechanical Technologies as a legal predecessor. In our summary [1] published on the 60th anniversary of the foundation of the Department, we have presented the results of the previous decades in detail. The most important task of the next period is to develop of the technological and personal generation change. In this paper, we intend to detail the professional activities of the past ten years with special emphasis on the infrastructure developments and new $R \& D$ topics that play important roles in this change of generation.
\end{abstract}

Keywords: University of Miskolc, Heat treatment, Surface Engineering 


\section{Bevezetés}

Az elmúlt évtizedben a hő- és felületkezelés terén egy jelentős hangsúlyeltolódás volt megfigyelhető Intézetünkben. A megelőző időszakra általánosságban az volt a jellemző, hogy a technológia-fejlesztés, a kutatások zöme az ipari üzemekkel való szoros együttmüködésben valósult meg, konkrét gyakorlati feladatok megoldását szolgálta, s jelentős volumenü, közvetlen ipari megrendelésre végzett gyártási szolgáltatást is teljesített a szakcsoport. Ilyen finanszírozási keretek között azonban érdemi infrastruktúra fejlesztés nem valósulhatott meg, és a szakmai publikációk száma is viszonylag kevés volt. Az elmúlt évtizedben azonban mind intézményi és intézeti szinten, mind a szakcsoport szempontjából olyan finanszírozási, projekttámogatási lehetőségek nyíltak meg, melyek hatékonyan segítették $\mathrm{K}+\mathrm{F}$ tevékenységünk körének szélesítését és az ehhez szükséges infrastruktúra fejlesztését. Emellett természetesen továbbra is rendelkezésre álltunk ipari partnereink megkeresése esetén a közös fejlesztő, gyártási tevékenységekre, melyekben nyugdíjba vonulását követően is számíthattunk Szabó Endre kollégánk sok évtizedes tapasztalataira és fáradhatatlan munkaszeretetére, egészen 2017-ben bekövetkezett haláláig, amiért azóta is hálával őrizzük emlékét.

Az említett új lehetőségek közül két TÁMOP projektet kell kiemelnünk, melyek kiváló lehetőségeket nyújtottak a Hö- és felületkezelés területén tervezett fejlesztésekhez:

- A Miskolci Egyetem „A felsőoktatás minőségének javítása Kiválósági Központokra alapozva a Miskolci Egyetem stratégiai kutatási területein" címü projektjének Innovatív anyagtechnológiák c. Tudományos Műhelye keretében megvalósuló Hőkezelés és Felülettechnológiák $\mathrm{K}+\mathrm{F}$ téma egyik legfontosabb célkitüzése az volt, hogy sokoldalúan megalapozzuk további pályázatok stratégiai és kutatási terveinek kifejlesztését. Mindezt az tette szükségessé, hogy Tanszékünkön a hö- és felületkezelés kutatás-fejlesztési és oktatási tevékenységében a megelőző évek jelentős változásokat és számos nehézséget hoztak. Újra kellett gondolnunk szakterületünk helyzetét, lehetőségeit az oktatás és a kutatás-fejlesztés egymásra épülő rendszerében, meg kellett felelnünk a nemzedékváltás és a technológiai generációváltás kihívásainak. Egy kivételesen nehéz gazdasági helyzetben életben kellett tartani és tovább kellett fejleszteni ipari kapcsolatainkat, $\mathrm{s}$ alkalmassá kellett válnunk a nemzetközi szakmai vérkeringésbe való aktívabb bekapcsolódásra. A projektzáró tanulmányban, s az eredményeinket összefoglaló cikkeinkben [2,3] bemutattuk annak a stratégiai tervnek a föbb elemeit, mely egy sokoldalú helyzetelemzésre, a nemzetközi szakirodalom értékelésére, ipari partnereinkkel folytatott konzultációk tapasztalataira és nemzetközi trendek elemzéseire épülve a soron következő projektünk megvalósíthatósági tanulmányának alapját képezte.

- A Jármüipari anyagfejlesztések: célzott alapkutatás az alakithatóság, hökezelés és hegeszthetöség témaköreiben - AUTOTECH c. TÁMOP-4.2.2.A-11/1/KONV-2012-0029 projekt keretében a Hő- és felületkezelés Tudományos Mühelye az előző projektben definiált három $\mathrm{K}+\mathrm{F}$ témában már szisztematikus kísérletsorozatok megvalósítására, további infrastrukturális fejlesztésekre, az eredmények tudományos publikációkban való megje- 
lentetésére, konferenciákon való disszeminációjára is sor kerülhetett. Ennek részleteit, s a projekt befejezését követően is folytatott munka eredményeit témakörönkénti bontásban mutatjuk majd be egy további fejezetben.

\section{Infrastruktúra fejlesztés}

A fenti két pályázat, illetve a párhuzamosan futó intézményi TIOP és ERFA pályázatok finanszírozásával lehetőségünk nyílt a korábbi évekhez képest jelentős infrastrukturális fejlesztésekre is. Elsőként egy plazmanitridáló berendezés beszerzése valósulhatott meg, melyet a későbbi fázisban korszerü aktív ernyős technológiai lehetőséggel egészíthettünk ki, egyúttal bővítve a gázkeverés és az adatgyüjtés lehetőségeit is. A berendezést gyártó marosvásárhelyi Plazmaterm szakemberei nemcsak a beüzemelésben, de szakmai tapasztalataik átadásával, folyamatos konzultációval is segítségünkre voltak.

Egy másik fontos infrastrukturális fejlesztési terület az edzőközeg-vizsgálat kísérleti feltételeinek megteremtése volt. Az első fázisban az edzőolajok termokinetikus paramétereinek meghatározásához a hülésgörbe elemzésén alapuló, szabványos (ISO 9950:1995, ASTM D 6200-01, ASTM D 6482-06) módszerére épülő vizsgálattechnika kialakítása valósult meg, egy ivf SmartQuench berendezés beszerzésével. További fejlesztési célkitüzéseink azt a célt szolgálták, hogy a hütés folyamatát jellemző szakaszok időbeli és helykoordináta szerinti változását vizsgálhassuk, végső soron a valós folyamat modellszámításokkal történő minél pontosabb közelítését tüzve ki célként. Ennek érdekében más kialakítású, több termoelemmel felszerelt próbatestek vizsgálatára van szükség, ezen kívül pedig - mivel a hütési folyamat során az egyes szakaszok közötti váltások optikai úton is megfigyelhetőek - olyan vizsgálati elrendezés kialakítása valósult meg, amellyel ezek a megfigyelések biztosíthatók. Így került sor a második fázisban egy speciálisan kialakított csőkemencét és hűtőtankot magába foglaló, több termoelem adatainak gyüjtésére és vizuális megfigyelésre is alkalmas vizsgálati rendszer kialakítására.

További infrastruktúra fejlesztési eredményekről a felületvizsgálati lehetőségeink bővítése terén számolhatunk be, a 90-es évek végén beszerzett karcvizsgáló berendezés mellett a TIOP projekt keretében elsőként egy moduláris felépítésü, sokoldalú vizsgálóberendezés tribológiai és nanoelemző modulja került beüzemelésre. Az UNMT-1 berendezéssel tribológiai vizsgálatok valósíthatók meg lineáris és körmozgással, változatos súrlódópár rendszerekkel szárazon és kenőanyag jelenlétében, tömbi anyagok és bevonatok tribológiai vizsgálata céljával. A további fejlesztési fázisban a felületvizsgálati lehetőségeinket is tovább bővíthettük, így egy Calotest (gömbsüveg koptató) berendezés beszerzése, továbbá Zeiss mikroszkópunk képelemző rendszerrel való bővítése mellett kisebb értékü kiegészítő berendezések beszerzése valósult meg.

A projektjeinkben folytatott tevékenységekkel nemcsak új, a régió versenyképességét növelő, a tovább hasznosítás lehetőségeit magában hordozó alapkutatási eredményeket kívántunk elérni, hanem egyúttal az intézmény kutatás-menedzsment képességeit és innovációs potenciálját is növeltük, a fiatal kutatók generációját felkészítve a nemzetközi szakmai életbe 
való aktív, sikeres bekapcsolódásra. Ehhez újabb lehetőséget nyújtott, hogy 2014-ben sikeres pályázatot nyújtottunk be a Nemzeti Kutatási Infrastruktúra Fejlesztési Útiterv - közismert nevén a NEKIFUT - pályázatára, így az intézeti honlapon túl [4], a NEKIFUT regiszterében is (https://regiszter.nekifut.hu/) megtalálhatják szakmai bemutatkozásunkat potenciális partnereink, az érdeklődő iparvállalatok és szakemberek, Hőkezelő és Müszaki Felülettudományi Laboratórium néven.

\section{Tudományos eredmények a föbb $K+F$ témakörökben}

A szakcsoport fontosabb kutatási eredményeit az alábbiakban a főbb tématerületek részletesebb bemutatásával kívánjuk sorra venni:

\subsection{Termokémiai kezelések}

Évtizedeken át a Miskolci Egyetem Mechanikai Technológiai Tanszékének hőkezelő szakcsoportja a termokémiai kezelések, azon belül is a nitridálás magas színvonalú kutatásfejlesztési tevékenységéről volt ismert a hazai szakmai körökben. Stratégiánk meghatározása során ezeknek az értékes tapasztalatoknak a megörzését és a szakterület újabb fejlesztési trendjeinek megismerését és adaptálását kiemelt prioritásként kezeltük. Az évtized első éveiben fiatal kollégáink bekapcsolódtak a hagyományos gáznitridálás és gázkarbonitridálás terén, az idősebb nemzedékkel közösen folytatott kutató-fejlesztő munkába. A vizsgálatok és a technológia-fejlesztés részben az egyes acélminőségek hőkezelésére irányuló tapasztalatszerzést szolgálták, ezek közül kiemelést érdemel a betétedzésü, kis karbontartalmú és gyengén ötvözött acélok karbonitridálásának vizsgálata [5]. Másrészt adott funkcionális tulajdonságokkal rendelkező termékek gyártási folyamatainak részeként megvalósítható, pl. nyomásos öntőszerszámok felületi tulajdonságait biztosító karbonitridálás eljárási paramétereinek vizsgálatára irányultak kísérleteink [6]. Kiemelést érdemel emellett a Floe eljárás módosított technológiai megoldásának vizsgálata is, az eljárás gazdaságosabbá tétele céljával [7].

A technológiai generáció-váltás terén kétségkívül a legnagyobb jelentőséggel a nitridálás korszerübb eljárásváltozatainak kutatása és alkalmazása bír. A hagyományos gáznitridálásnál jelentősen kedvezőbb költséghatékonyságú, kisebb energia-felhasználású és kisebb környezetterhelést okozó plazmanitridálás hazánkban még nem rendelkezik jelentős múlttal és tapasztalati háttérrel.

A NITRION 10 típusú plazmanitridáló berendezés 2013. tavaszán történt beszerzésével megnyílt a lehetőség arra, hogy összehasonlító vizsgálatokat végezzünk a hagyományos gázközegü nitridálás és a korszerübb, környezetkímélőbb plazmanitridáló technológia alkalmazásával létrehozott felületi rétegek tulajdonságait illetően [8]. Az AUTOTECH projekt, valamint számos TDK és szakdolgozat keretében szisztematikus vizsgálat sorozatokat folytattunk annak érdekében, hogy minél több acélminőségre szerezhessünk tapasztalatokat a kísérleti paraméterek és a rétegek tulajdonságainak összefüggéseiről [9]. 
Az AUTOTECH projekt Hö- és Felületkezelési Tudományos Műhelyének egyik legfontosabb eredményeként tekintünk annak a hiánypótló, magyar nyelvű monográfiának a megjelentetésére [10], mely a termokémiai kezelések és elsődlegesen a nitridálás témakörét megfelelő alapossággal tárgyaló szakirodalmi összefoglalót és saját kutatási eredményeinket egyaránt tartalmazza. Monográfiánk felépítésének, struktúrájának meghatározásában az a koncepció érvényesült, hogy az általánostól a specifikus felé haladva áttekintést adjunk a Hö- és felületkezelés napjainkban tapasztalható jelentőségéről és fejlesztési trendjeiről, bemutassuk az alkalmazható felületmódosító és bevonatoló technológiák széles körét, a technológiák kiválasztásának főbb szempontjait. Ezt követően a gépipar és a jármüipar legjelentősebb, termokémiai felületmódosító eljárásait, azon belül pedig a nitridálás és karbonitridálás elvi hátterét, eljárásváltozatait és a létrehozható felületi rétegek szerkezetének és tulajdonságainak összefüggéseit részletezzük, továbbá a duplex kezelések lehetőségeire is kitekintést nyújtunk. A hagyományos és korszerü felületvizsgálati lehetőségek - kiemelten a tribológiai vizsgálatok - áttekintése során a projektben megvalósult kutatások eredményeiről is számot adunk, megkülönböztető tipográfiai megjelenítéssel (1. ábra). A monográfia megjelenését követően számos szakmai rendezvényen kaptunk ipari szakemberektől igen pozitív visszajelzést a kiadvány tartalmáról, annak hiánypótló jelentőségéről.
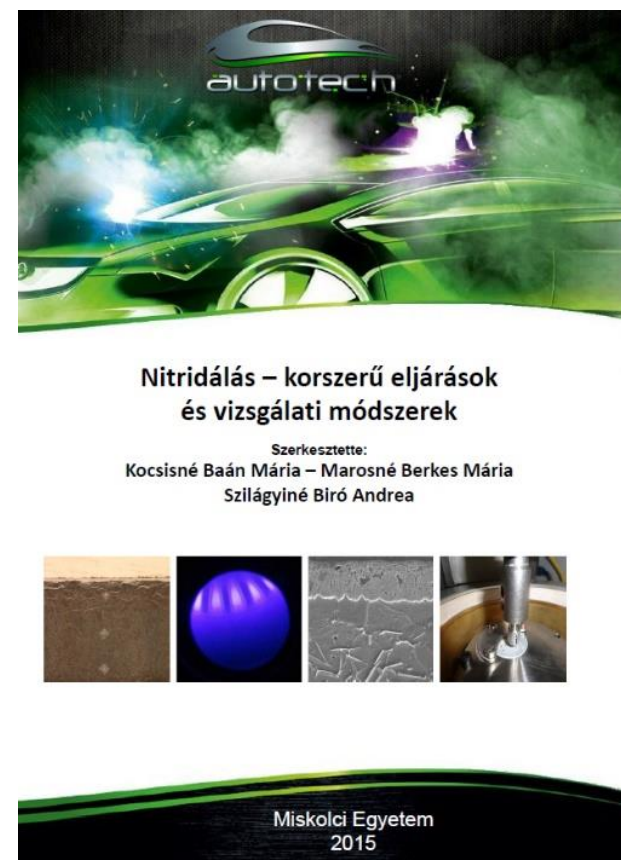

a)

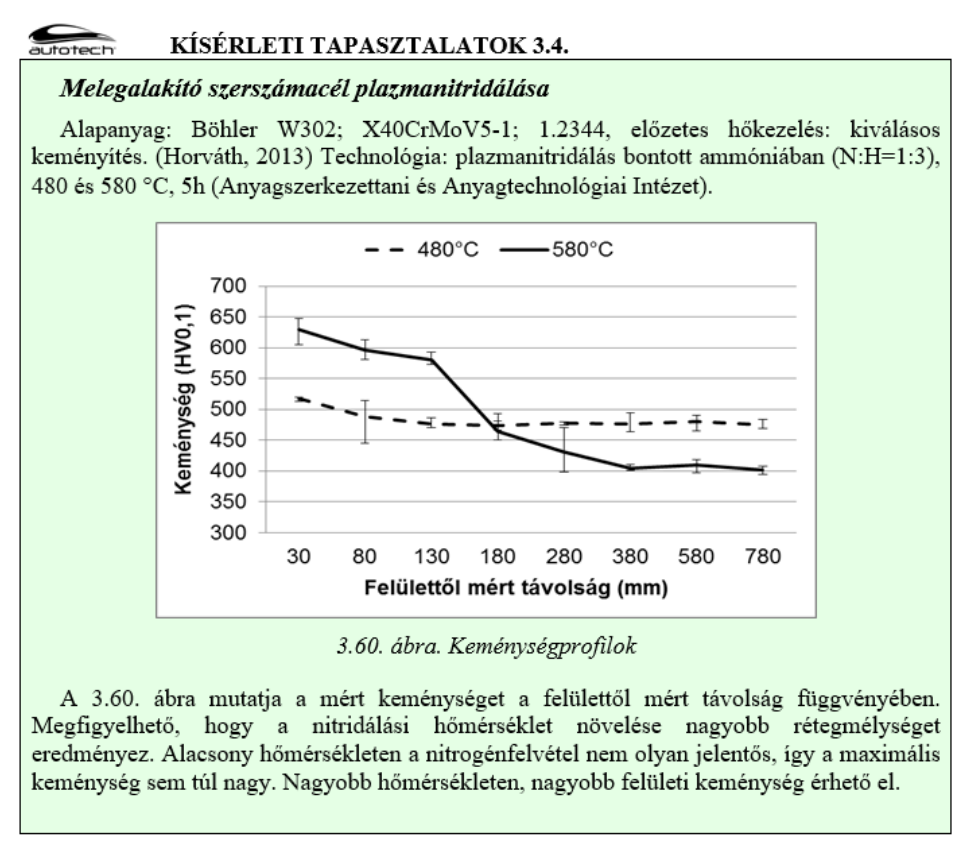

b)

1. ábra. Monográfiánk boritólapja (a) és egy példa a saját kísérleti eredményeink bemutatásának tipográfiai megjelenitésére (b) 
A plazmanitridálás szélesebb körü alkalmazásának egyik akadálya a viszonylag igényes adagösszeállítás és az egyenletes réteg kialakításával kapcsolatos nehézségek (élhatás, üregkatód jelenség, hőmérséklet-szabályozási problémák, ívégési nyomok).

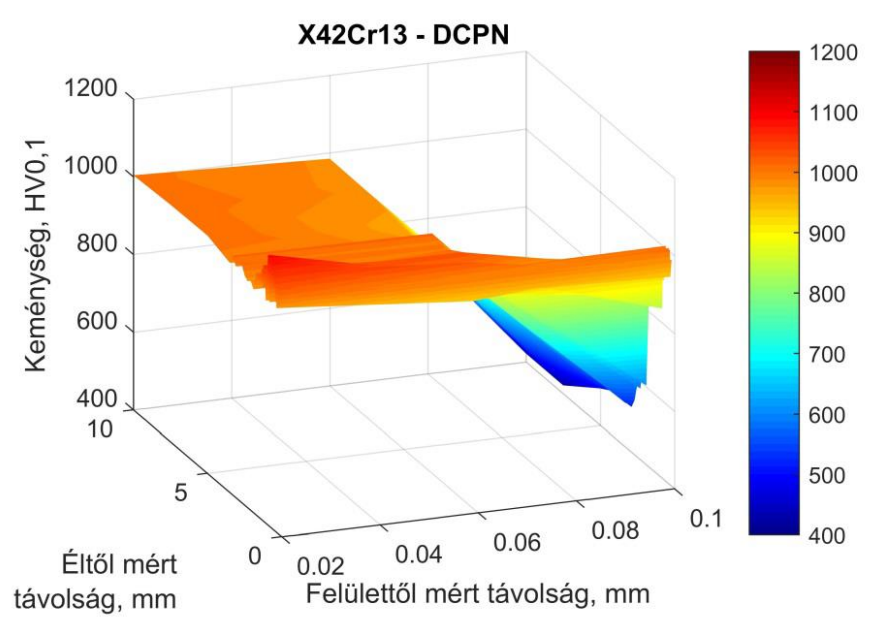

Keménységtérkép X42Cr13 acélra, aktív ernyö nélküli plazmanitridálás esetén
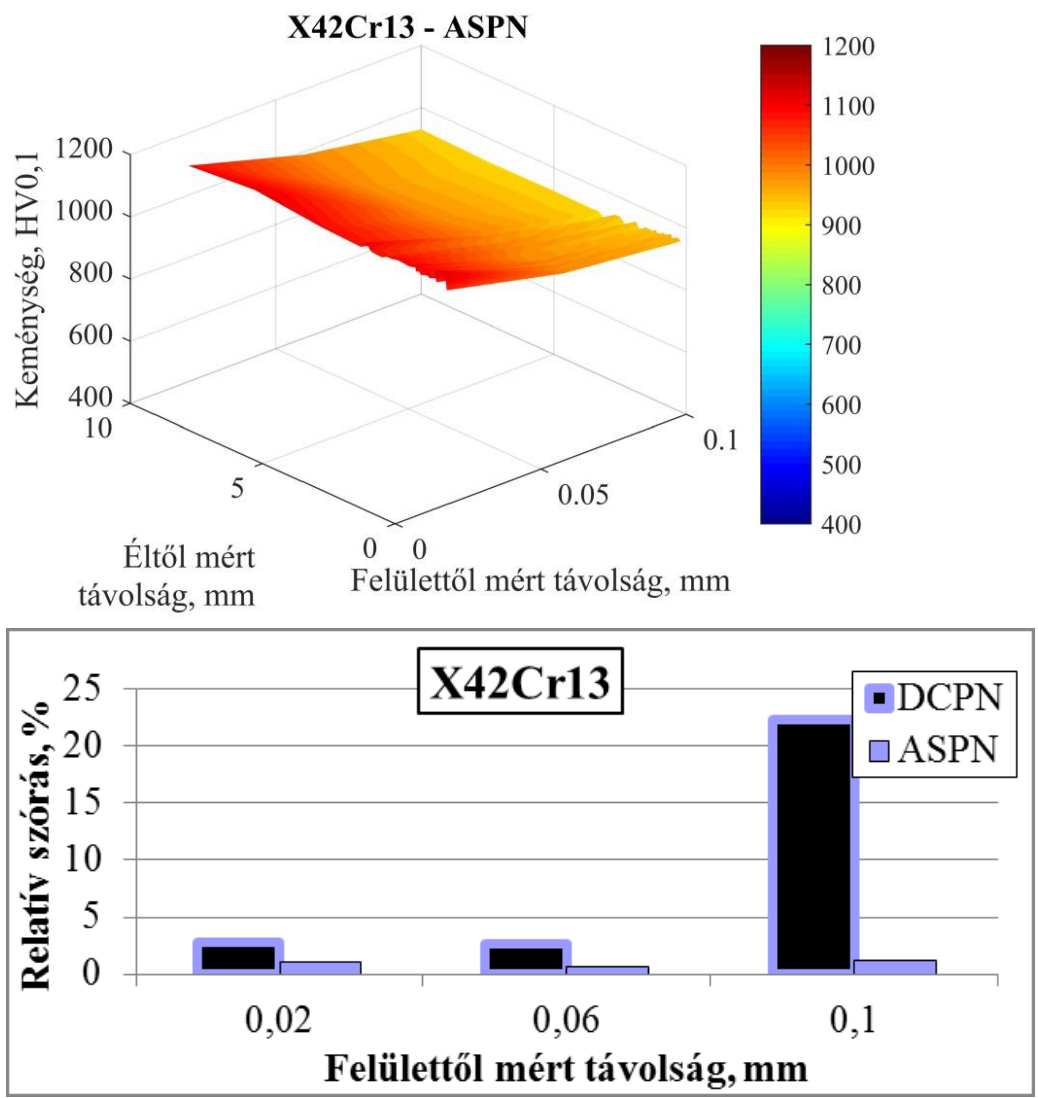

Keménységtérkép X42Cr13 acélra, aktív ernyös plazmanitridálás esetén

Mikrokeménység mérési eredmények relatív szórása a felülettöl mért távolság függvényében, $\quad \mathrm{X} 42 \mathrm{Cr} 13$ acélra

2. ábra. Az aktív ernyö alkalmazásának hatása a felületi réteg homogenitására [12] 
Ezen hátrányok leküzdésére igen hatékony segítséget kínál a nemzetközi kutatások egyik hangsúlyos területét jelentő aktívernyős eljárásváltozat, melynek vizsgálattechnikai feltételeit az AUTOTECH projekt keretében sikerült megvalósítanunk. Az aktív ernyős plazmanitridálás (ASPN) lényege, hogy a kisülés egy részének, vagy egészének áthelyezése egy közvetítő ernyőre megoldást kínálhat a hagyományos plazmanitridálási technológia (DCPN) nehézségeit illetően, s emellett tovább bővíti a technológia alkalmazhatósági körét. Érthetően ezért e területen nemzetközileg is intenzív kutató munka folyik, ezen belül az egyik legfontosabb, tisztázásra váró kérdés a másodlagos feszültség (BIAS) hatása a réteg kialakulására és tulajdonságaira. Ennek a témának a kutatása szakcsoportunkban a projektidőszak lezártát követően egy PhD dolgozat keretében folytatódott [11], és vezetett jelentős eredményekre [12].

Az aktív ernyős plazmanitridálás kutatási eredményei jelentősen hozzájárulhatnak az eljárás ipari alkalmazásának elterjedéséhez, hasznosítva az alábbi lehetőségeket:

- a másodlagos feszültség anyagminőség-függő, hatásosság szempontjából szükséges minimális értékének ismerete segíthet a technológiai költségek csökkentésében, valamint a hagyományos plazmanitridáló berendezések áttervezésében, átalakításában,

- az aktív ernyő alkalmazásával intenzívebbé tett nitrogénfelvételnek köszönhetően a technológiai idő rövidíthető, vagy ugyanannyi idő alatt nagyobb rétegmélység érhető el,

- az aktív ernyő alkalmazásával az alkatrészek felületi tulajdonságai homogénebbek (2. ábra), amely különösen kisebb méretü darabok esetén és nagyobb élterheléskor fontos.

\subsection{Edzőközegek korszerü vizsgálati módszerei}

Köztudott, hogy az elsősorban kopási igénybevételnek kitett acél munkadarabok szokásos hőkezelési folyamatának kritikus részművelete az edző hatású lehütés, mely döntően meghatározza a kialakuló szövetszerkezetet és a mechanikai tulajdonságokat a munkadarab keresztmetszetében. Az alkalmazott hütőfolyadékok edzési teljesítménye az alkatrész sajátosságain kívül a közeg hőelvonási vagy hütési képességének is függvénye. A közeg hőelvonásának karakterisztikáját a közeg típusa, hőmérséklete, áramlási viszonyai, koncentrációja, szennyezettsége határozza meg. Jelentős nemzetközi érdeklődés tapasztalható a témakör kutatása és eredményeinek adatbázisba gyüjtése iránt, melyet a nemzetközi szakmai világszervezet, az IFHTSE (International Federation for Heat Treatment and Surface Engineering) által kezdeményezett és menedzselt nemzetközi Liquid Quenchant Database projekt fémjelez. A projekt célja olyan mérési és számítási módszer kidolgozása és bevezetése, mely a valóságban lejátszódó hőátadási folyamat pontos elemzése révén az autóiparban is gyakran alkalmazott hőkezelési technológiák optimalizálását teszi lehetővé, ennek révén szignifikánsan kisebb gyártási költség, kevesebb energiafelhasználás és ennek következményeként kisebb környezeti terhelés mellett megbízható, növelt minőség elöállítása valósulhat meg. Ehhez a nemzetközi kutatási projekthez kapcsolódott az a Miskolci Egyetemen előzmények nélküli $\mathrm{K}+\mathrm{F}$ téma, melyben a nemzetközi partnerek mellett elsődlegesen az Óbudai Egyetem szakembereivel alakíthattunk ki stratégiai együttmüködést. 
Kutatásaink fö területei, melyek eredményeit hazai és nemzetközi szakmai rendezvényeken illetve folyóiratokban publikáltuk, a következők voltak:

- vízbázisú polimeradalékos edzőközegek esetén vizsgáltuk a hőmérséklet, az áramlási sebesség és a koncentráció együttes hatását $[13,14,15,16]$

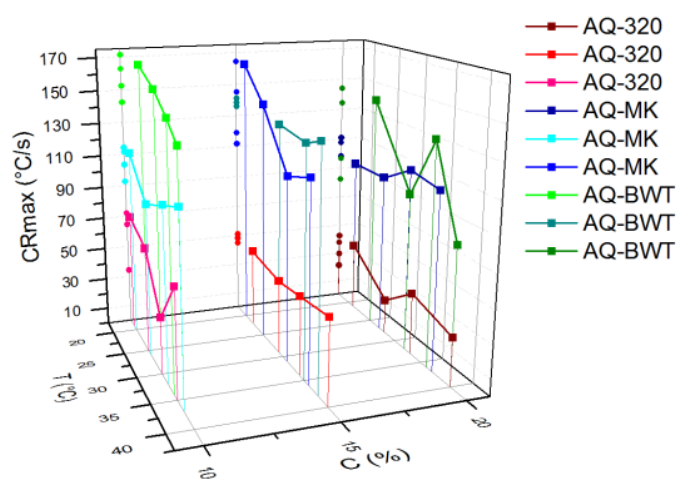

a)

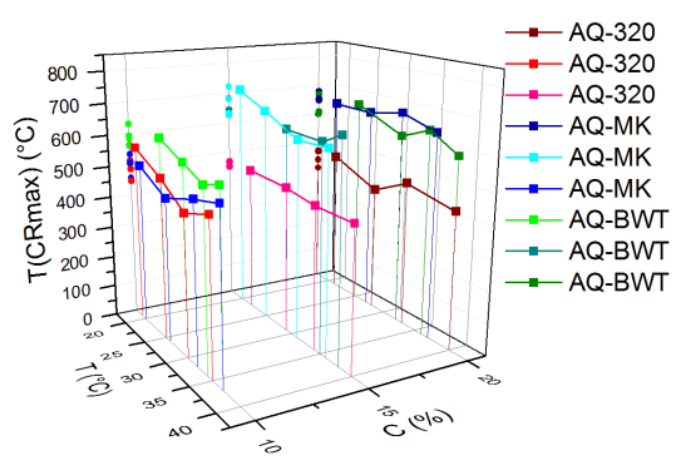

b)

3. ábra. Összehasonlitás vízbázisú polimeradalékos edzöközegek CRmax értékei (a) és T(CRmax) értékei (b) között

- három különböző típusú ásványi olaj karakterisztikus adatait hasonlítottuk össze, vizsgálva egyúttal a hütőképességét befolyásoló paraméterek közül a fürdő kezdeti hőmérsékletének hatását, majd ezek közül két típust hasonlítottunk össze kilenc különböző növényi eredetü (napraforgó, oliva, repce, szója, kukorica-csíra, mogyoró, rizs, pálma és kókusz) olajjal, ugyancsak vizsgálva a fürdő kezdeti hőmérsékletének hatását is [17]. Az ásványi olajok vizsgálatának jelentősége azok környezetre gyakorolt hatása és kezelésük nehézségei miatt került a nemzetközi kutatások elöterébe.
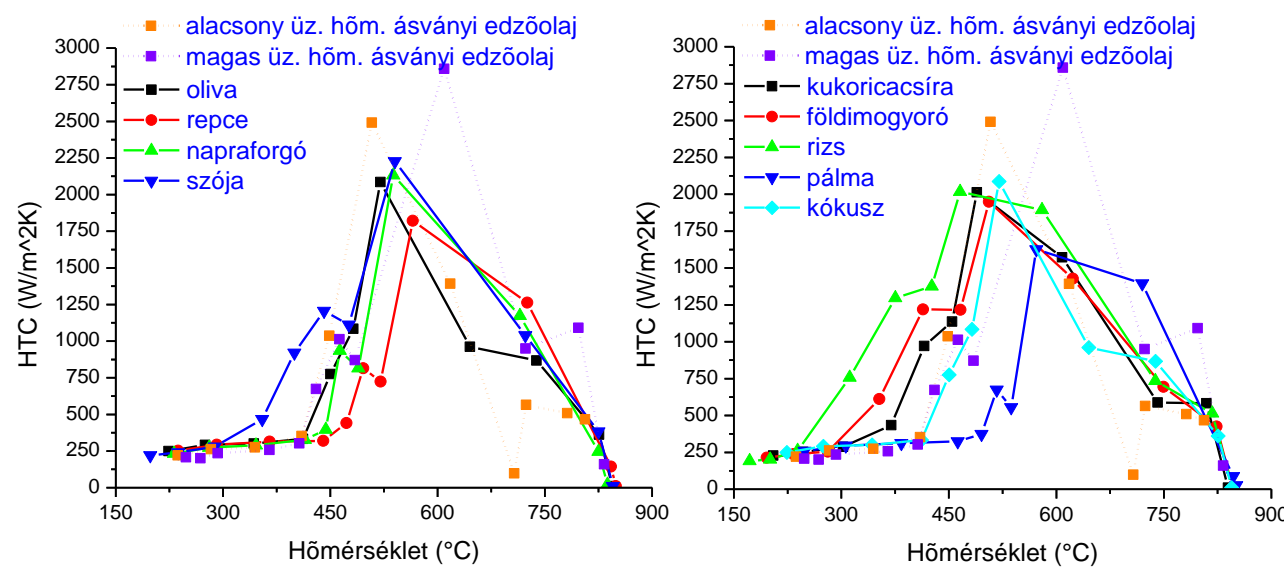

4. ábra $A$ höátadási együttható hömérséklet szerinti változása $35^{\circ} \mathrm{C}$-os közeghőmérséklet esetén [17]

Az AUTOTECH projekt keretében végzett kutatások eredményeinek összefoglaló tanulmányát egy közel száz oldalas, önálló monográfia keretében is közreadtuk [18]. 


\subsection{Hö- és felülettechnológiai folyamatok modellezése és szimulációja}

A digitalizáció napjainkban az élet minden területén, így az anyagtechnológiai kutatások terén is számos innovatív lehetőséget nyit a kutatók elött. Magában foglalják e lehetőségek a nagy számú mérési adatok statisztikai értékelésére alapozott tulajdonságbecslést [19] és a becsléssel meghatározott anyagtulajdonságok kísérleti úton történő validálását, csakúgy, mint a komplex, bonyolult folyamatok modellezésének, szimulációjának lehetőségeit. Szakcsoportunkban már a korábbi időszakban is jelentős eredményekröl számolhattunk be [20], lézeres felületedzés folyamatainak Sysweld programmal történő, végeselemes modellezése témakörben. Az AUTOTECH projekt finanszírozásának köszönhetően fiatal kutatóink egy csoportja nemzetközi képzési programon vehetett részt Csehországban, megismerve e sokoldalú szoftvercsomag legfrissebb verziója alkalmazásának mérnöki lehetőségeit. A modellezési feladatok esetenként szakmai partnerintézményekkel való együttmüködés keretében konkrét alkatrészek - pl. cementált görgők - felületi tulajdonságainak élettartam elemzés céljából történő meghatározására irányultak, numerikus modellezés módszerével [21].

Az intézetünk által művelt szakterületek, az anyagtechnológiai folyamatok mind alaposabb megértését és modellezését egy 2012. végén beszerzett nagy értékű berendezés, a Gleeble 3500 fizikai szimulátor is jelentősen támogatja [22]. A Hőkezelés területén a sokoldalú lehetőségek közül az alábbi folyamatok vizsgálatára végeztünk eddig kísérleteket:

- Nem egyensúlyi folyamatok átalakulási diagramjainak felvétele (CCT, TTT), speciális próbatest hevítése során alkalmazott keresztirányú dilatométeres méréssel (5. ábra), majd a kialakult mikroszerkezet ellenőrzésére metallográfiai vizsgálatok végzése néhány kiválasztott lehülési sebesség esetében [23].

- Karbidkiválás kinetikájának vizsgálata és maradék ausztenit vizsgálata megeresztés függvényében.

- Oxidációs szín hőmérséklet-függésének meghatározása.

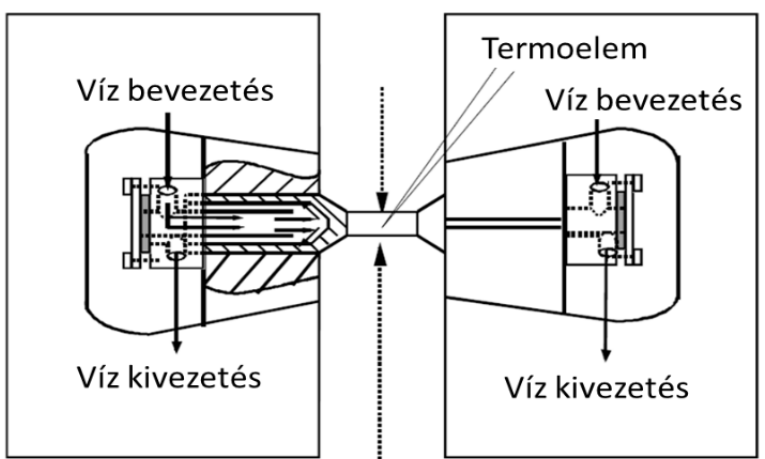

Dilatométer, keresztirányú méretváltozás

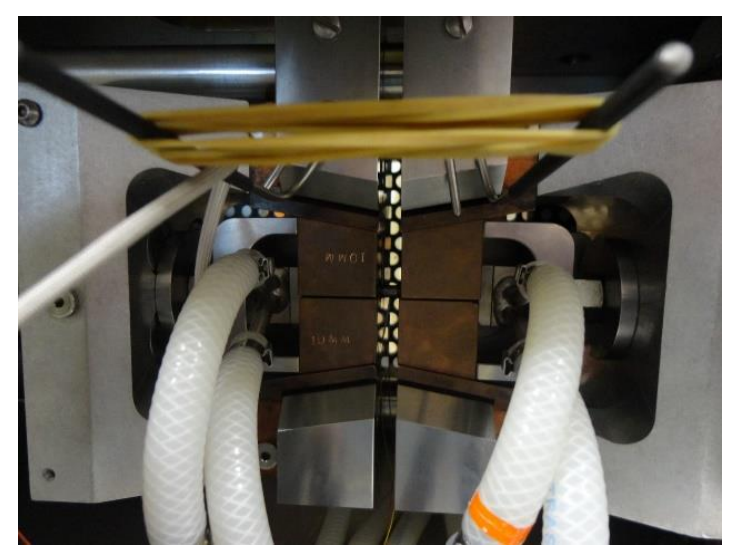

5. ábra. A folyamatos hütésü átalakulási diagram felvételéhez alkalmazott vizsgálati elrendezés sematikus rajza és felvétele a Gleeble 3500 berendezéssel 


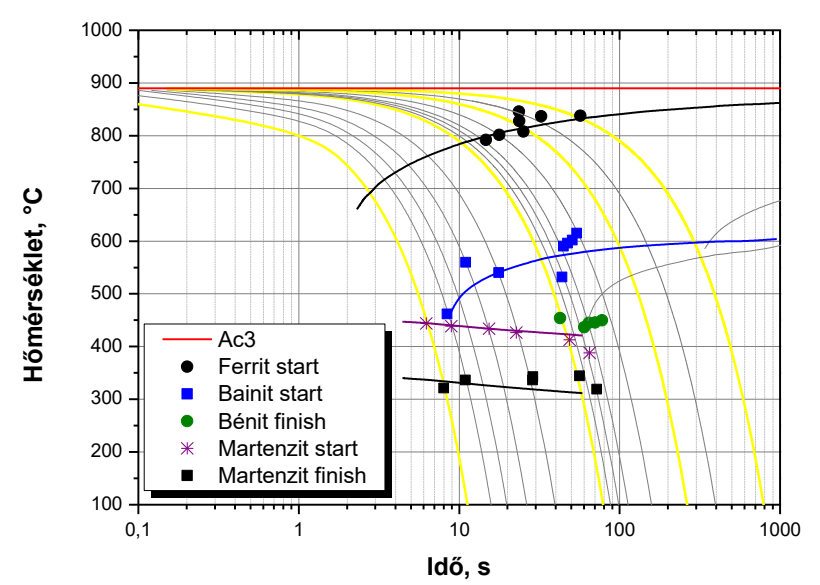

6. ábra. S960 típusú acél folyamatos átalakulási diagramja fizikai szimulációval meghatározva

Oktatóink fontos feladatuknak tekintik hallgatóink felkészítését a digitalizáció nyújtotta előnyök széles körü kiaknázására, így oktatási programunkban számos tantárgy keretében ismertetjük meg diákjainkkal a számítástechnika mérnöki alkalmazási lehetőségeit [24].

\subsection{Felületi rétegek vizsgálata}

A hő- és felülettechnológiák fejlesztése területén természetesen kulcsfontosságú feladat a létrehozott felületi rétegek sokoldalú, megbízható vizsgálata. Méréstechnikai lehetőségeink és eredményeink rövid áttekintése érdekében az alábbi vizsgálati tapasztalatokra mutatunk be egy-egy példát ebben a fejezetben.

A felületmódosító eljárások minősítése során az egyik legfontosabb, geometriai jellemző a rétegmélység, melynek vizsgálatára hagyományosan a keresztmetszet mikroszkópi csiszolatán történő mérést alkalmazzuk [25], de az eredetileg bevonatolt felületek rétegvastagságának mérésére kifejlesztett calotest vizsgálat alkalmazási lehetőségét is vizsgáltuk [12]. Hasonlóan, a nagy kopásállóságú bevonatok adhéziós kötéserősségének vizsgálatára kifejlesztett karcvizsgálatnak a nitridált kéreg jellemzésére való alkalmazási lehetőségével is foglalkoztunk [26].

A felületi réteg kémiai összetételét is megváltoztató felületmódosító, illetve bevonatoló eljárások - s így többek között a nitridálás - esetén különösen hasznos vizsgálattechnikai megoldás a GDOES eljárás, mely a kémiai összetétel rétegmélység szerinti analízisére ad lehetőséget. A Miskolci Egyetem Müszaki Anyagtudományi Karán, a berendezést üzemeltető szakemberekkel való együttmüködésben ilyen típusú vizsgálatok elvégzésére is sor kerülhetett [27]. 
Tekintettel arra, hogy a nitridálás alkalmazásának egyik leggyakoribb oka a kopásállóság növelése, a kedvezőbb tribológiai tulajdonságok elérése, így az előbbiekben felsorolt vizsgálati módszerek mellett a legnagyobb figyelmet a tribológiai vizsgálatokra fordítottuk $[12,28$, 29].

\section{Szakmai kapcsolatrendszer, hálózati együttmüködés}

Nem vitatható, hogy globalizálódó világunkban a kutatás-fejlesztés eredményessége jelentős mértékben függ a szakmai, hálózati együttmüködés, kiemelten a nemzetközi kapcsolatrendszer hatékonyságától. A forrásteremtés elsődleges lehetőségei a pályázatok, melyek az infrastruktúrájuk és tudásuk, tapasztalataik megosztásában hatékonyan együttműködő konzorciumok számára biztosítanak jelentős támogatásokat. A Hő- és felületkezelő szakcsoport tevékenységének jövőbeli sikerei nagyban függenek attól, hogy a fiatal generáció milyen mértékben tud beintegrálódni elődeinek hazai és nemzetközi kapcsolatrendszerébe. E szempontból is kiváló lehetőséget biztosítottak a bemutatott projektek, melyek támogatásával fiatal kollégáink számos nemzetközi rendezvényen mutathatták be tudományos eredményeiket, tovább bővítve egyúttal szakmai kapcsolat-rendszerünket.

A stratégiailag kiemelt jelentőségü járműipari szektorban a hazai hálózati együttműködés szempontjából röviden érdemes megemlítenünk egy további, országos jelentőségü TÁMOP projektet is - TÁMOP-4.1.1.C-12/1/KONV-2012-0002: Járműipari Felsőoktatási és Kutatási Együttmüködés projekt - melyben Intézetünk szintén jelentős szerepet vállalt. Ennek egyik témakörében (Új oktatási kínálat megismertetése - life long learning népszerüsítése) a kutatási eredményeknek az oktatásba való becsatornázására mutattunk be innovatív módszereket és megoldásokat az országos hálózat tagjainak [30].

Korábbi nemzetközi, EU támogatású oktatásfejlesztési projektjeinkben stratégiai partnerséget alakítottunk ki számos európai felsőoktatási intézménnyel és iparvállalattal, továbbá a hő- és felületkezelés szakmai világszervezetével, az IFHTSE (International Federation for Heat Treatment and Surface Engineering) szervezetével. E szövetségnek 2012-2015. között a Miskolci Egyetem formálisan is tagja volt, egyedüli magyar szervezetként képviselve a hazai szakembergárdát. Az említett nemzetközi oktatásfejlesztési projektjeinkben csakúgy, mint az IFHTSE tevékenyégébe való aktív bekapcsolódásunk lehetőségét tekintve kiemelt szerepet játszott Dr. Kolozsváry Zoltán professzor úr, akinek sokoldalú szakmai segítségéért köszönetet kell mondanunk. Több mint két évtizede folyamatosan számíthatunk rendkívüli szakmai tudására és segítőkészségére, a termokémiai kutatások világszerte elismert szaktekintélyeként az elmúlt időszakban infrastruktúránk fejlesztésében is tevékenyen részt vállalt, miután az általa vezetett marosvásárhelyi Plasmaterm cég fejlesztésében valósult meg plazmanitridáló berendezésünk és annak aktív ernyős továbbfejlesztése. Monográfiánk lektorálásában, szakdolgozatok, disszertációk, tananyagok, tanulmányok és cikkek bírálatában, előadások tartásában megkérdőjelezhetetlen szakmai tudása biztos tudományos hátteret jelentett a fő célkitüzésünk, a technológiai generációváltás elősegítésében éppúgy, mint kutatási céljaink kitüzésében. 


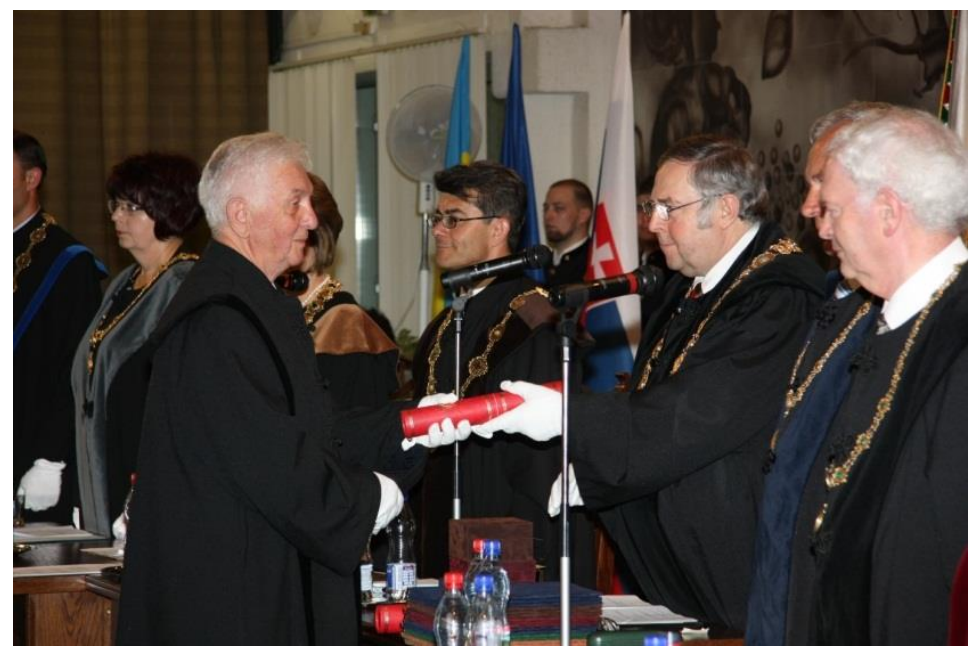

7. ábra. Prof. Dr. Kolozsváry Zoltán átveszi a tiszteletbeli doktori cím kitüntetését a Miskolci Egyetem rektorától 2012. nyarán

A nitridálás legaktuálisabb kérdéseinek kutatása mellett az AUTOTECH projekt keretében egy olyan $\mathrm{K}+\mathrm{F}$ témakörben kezdtük meg munkánkat, melyben - mint azt a 3.2. fejezetben részleteztük - szintén kiemelt jelentőségü volt a nemzetközi együttmüködés. Az IFHTSE nemzetközi LQD projekthez való kapcsolódásunk vonatkozásában meg kell említenünk hazai stratégiai partnerünkként az Óbudai Egyetemet, s név szerint is Dr. Felde Imrét, a nemzetközi projekt szakmai vezetőjét.

A hö- és felületkezelés olyan komplex műszaki, mérnöki feladatkör, amely átfogó és mélyreható anyagtudományi alapismereteket, tapasztalatot és innovatív, folyamatos fejlődésre, megújulásra képes szemléletmódot igényel. Jóllehet e téren is müködnek multinacionális nagyvállalatok, ám azok is többnyire kis és közepes méretü üzemek hálózataiként épülnek fel, más szóval a hő- és felületkezelés fő szereplői elsősorban a KKV-k. E szektor versenyképessége döntően annak a függvénye, hogy magas hozzáadott értékü termékekkel és szolgáltatásokkal, a piaci igényekre való rugalmas reagálással képes legyen a beszállítókkal szemben támasztott elvárások teljesítésére. Ugyanakkor önállóan ezek a cégek $\mathrm{K}+\mathrm{F}$ tevékenységre nem tudnak vállalkozni, a transznacionális hálózati együttmüködés, az alapkutatástól a felhasználókig terjedően a kutatás-fejlesztésben érintettek közötti kooperáció e téren ezért kiemelt jelentőséggel bír. Ezért igen nagyra értékeljük az elmúlt évtizedben velünk együttmüködő hazai szakmai partnerkapcsolatainkat, így többek között a TS Hungary, a Höker Kft., a ZF Hungary és az Autóipari Klaszter (NOHAC) K+F tevékenységeinkben és oktatási feladatainkban vállalt aktív közremüködését.

Stratégiai terveink és valamennyi $\mathrm{K}+\mathrm{F}$ projektünk célkitüzései között hangsúlyos vállalásunk volt a tudományos eredményeknek az oktatásba való becsatornázása, innovatív oktatási 
módszerek alkalmazásával az élethosszig tartó tanulás feltételeinek folyamatos fejlesztése szakterületünkön. E tevékenységünk eredményeinek elismeréseként tekinthető, hogy tapasztalatainkat több alkalommal is bemutathattuk a Cambridge-i Egyetem által szervezett nemzetközi Materials Education Symposium rendezvénysorozatának konferenciáin [31]. Hasonlóan az oktatásfejlesztés terén kifejtett több évtizedes tevékenység nemzetközi elismerését fejezte ki, hogy az ASM International 100 éves fennállásának ünnepi rendezvénysorozatán a szakcsoport vezetését 2011-2015 között ellátó Kocsisné dr. Baán Mária „Alpha Sigma Mu Fellowship" kitüntetésben részesült.

\section{5. Összefoglalás}

A közelmúltban megvalósult $\mathrm{K}+\mathrm{F}$ projektek Hő- és Felületkezelő Tudományos Műhelyének tevékenysége az egyik legdinamikusabban fejlődő multidiszciplináris terület, a müszaki felülettudomány témakörére irányult, és jelentősen hozzájárult ahhoz, hogy az évtized elején megfogalmazott stratégiai célok mentén a megújulás folyamata megindulhasson. Bővülő $\mathrm{K}+\mathrm{F}$ infrastruktúrájának és kiváló nemzetközi kapcsolatainak révén a Tudományos Műhely sokoldalúan szolgálja a képzés és a tehetséggondozás feladatait, bővíti a felsőoktatási kutatási kapacitást, alkalmas az innovációk dinamizálására és így a kutatóinak nemzetközi vérkeringésbe való bekapcsolódására is.

Kutatási programjaink megvalósításába nagy számban vontunk be fiatal kutatókat, alap- és mesterszakos hallgatókat, ill. $\mathrm{PhD}$ hallgatókat. A projekt-finanszírozás lehetőséget teremtett arra is, hogy fiatal kollégáink és diákjaink olyan jelentős szakmai konferenciákon mutathassák be eredményeiket, mint pl. a szakmai világszervezet, az IFHTSE Kongresszusa, vagy a Junior Euromat 2014 konferencia.

Összefoglalóan elmondható, az egy évtizede megkezdett folyamatnak fó célkitüzése, hogy a Tanszék múltbeli értékeinek megőrzésére alapozva, a pályázati támogatási és együttmüködési lehetőségeket maximális hatékonysággal hasznosítva egy fiatal, dinamikus kutatói csoportot hozzunk létre, versenyképes tudással és kutatás-menedzsment készségekkel alkalmassá váljunk a nemzetközi kutatás-fejlesztési tevékenységbe való mind aktívabb bekapcsolódásra.

\section{Köszönetnyilvánítás}

A kutató munka az Európai Unió és a magyar állam támogatásával, az Európai Regionális Fejlesztési Alap társfinanszírozásával, a GINOP-2.3.4-15-2016-00004 projekt keretében valósult meg, a felsőoktatás és az ipar együttmüködésének elősegítése céljából. 


\section{Irodalomjegyzék}

[1] Kocsisné Baán M., Frigyik G., Kovács F., Szabó E.: A Miskolci Egyetem Mechanikai Technológiai Tanszéke Hőkezelő Szakcsoportjának kutatási tevékenysége: 2001-2010, Gép, 62. k. (2011.) 4. sz. pp. 38-41

[2] Tisza M., Török I., Kocsisné Baán M.: Innovatív anyagtechnológiák, Gép, 63.k. 1. sz. pp. 3-8.

[3] Kocsisné Baán M., Frigyik G., Kuzsella L., Koncsik Zs., Szilágyiné Bíró A., Kerekes G.: Trendek és tervek a hő- és felületkezelés területén, GÉP, LXIV. évf. 2.sz 2013. pp. 3-6.

[4] Hőkezelő és Műszaki Felülettudományi Laboratórium http://www.met.unimiskolc.hu/index.php/site/LaborHokezeles_NEKIFUT

[5] Bíró A., Szabó E., Tisza M.: Betétedzésű acélok karbonitridálása különböző hőmérsékleten, In: Tóth, Tamás (szerk.) XXIV. Hőkezelő és Anyagtudomány a Gépgyártásban Országos Konferencia és Szakkiállítás külföldi résztvevőkkel, Dunaújváros, Magyarország: Gépipari Tudományos Egyesület, Hőkezelö Szakosztály, (2011.) pp. 74-79., 6 p.

[6] Szabó E., Szilágyiné Bíró A.: Nyomásos öntőszerszámok élettartamát befolyásoló tényezők, In: Tóth, Tamás (szerk.) XXVI. Hőkezelő és anyagtudomány a gépgyártásban országos konferencia és szakkiállítás külföldi résztvevőkkel, Budapest, Magyarország: HTSART Nyomda és Kiadó, (2014) pp. 226-231. 6 p.

[7] Szilágyiné Bíró A., Szabó E., Tisza M.: Surface layers produced by modified Floe ferritic nitrocarburising, In: Berecz, T; Májlinger, K; Orbulov, IN; Szabó, PJ (szerk.) Materials Science, Testing and Informatics VII : Selected, peer reviewed papers from the 9th Hungarian Conference on Materials Science. October 13-15, 2013, Balatonkenese, Hungary, Zürich, Svájc : Trans Tech Publications, (2015) pp. 253-258., 6 p. https://doi.org/10.4028/www.scientific.net/MSF.812.253

[8] Szilágyi Bíró A., Kocsis Baán, M.: Comparison of Gas and Plasma Nitrocarburised surface layer of 16CrMo5 Steel, In Proc.. Hans-Werner, Zoch (szerk.), Reinhold, Schneider (szerk.), Thomas, Lübben (szerk.) European Conference on Heat Treatment and 21st IFHTSE Congress,12-15 May 2014, Munich, Germany, Proceedings, pp 551-558, $8 \mathrm{p}$.

[9] Kuzsella L., Frigyik G., Kocsisné Baán M., Varga Zs., Sávolyi S.: Plazmanitridálási kísérletek szerszámacélokon, In: Tóth, Tamás (szerk.) XXVI. Hőkezelő és anyagtudomány a gépgyártásban országos konferencia és szakkiállítás külföldi résztvevőkkel, Budapest, Magyarország : HTSART Nyomda és Kiadó, (2014) pp. 246-256., 10 p.

[10] Cserjésné Sutyák Á., Frigyik G., Kocsisné Baán M., Kuzsella L., Marosné Berkes M., Szabó E., Szilágyiné Biró A., Kocsisné Baán M. (szerk.) Nitridálás - korszerü eljárások és vizsgálati módszerek, Miskolc, Magyarország: Miskolci Egyetem (2015), 296 p.

[11] Szilágyiné Bíró A.: Aktív ernyős plazmanitridálás gyakorlati tapasztalatai gyengén és erősen ötvözött nemesíthető acélokon In: Tóth T., Hohol R. (szerk.) XXVII. Hőkezelő és anyagtudomány a gépgyártásban országos konferencia és szakkiállítás külföldi rész- 
vevőkkel Veszprém, Magyarország : Gépipari Tudományos Egyesület, Hőkezelő Szakosztály, (2016) pp. 185-189. , 5 p.

[12] Szilágyiné Bíró A.: Aktív ernyős plazmanitridálás BIAS paraméterének hatása a rétegszerkezetre 102 p. Miskolci Egyetem, Sályi István Gépészeti Tudományok Doktori Iskola, Disszertáció 2018

[13] Kerekes G., Kocsisné Baán M., Felde I.: Edzéshez alkalmazott hütőközegek minősítése, GÉP 64 : 8 pp. 51-54., 4 p. (2013)

[14] Kerekes G., Kocsisné Baán M., Felde I.: A hőmérséklet, az áramlási sebesség és a koncentráció együttes hatása vízbázisú polimeradalékos közeg hütőképességére, In: Csibi, Vencel-József (szerk.) OGÉT 2014: XXII. Nemzetközi Gépészeti Találkozó, Kolozsvár, Románia: Erdélyi Magyar Müszaki Tudományos Társaság (EMT), (2014), pp. 178-181. , 4 p.

[15] G. Kerekes, M. Kocsisné Baán, I. Felde: The join effect of temperature, agitation and concentration on the cooling power of a waterbased polymer quenchant, Proceedings, European Conference on Heat Treatment and 21st IFHTSE-Congress, 2014. május 1216., Munich, pp. 261-266

[16] G. Kerekes, M. Kocsisné Baán, I. Felde: Evaluation of Quenchant's Cooling and Hardening Performance, In: Berecz, T; Májlinger, K; Orbulov, IN; Szabó, PJ (szerk.) Materials Science, Testing and Informatics VII : Selected, peer reviewed papers from the 9th Hungarian Conference on Materials Science. October 13-15, 2013, Balatonkenese, Hungary, Zurich, Svájc: Trans Tech Publications, (2015.) pp. 345-350, 6 p. https://doi.org/10.4028/www.scientific.net/MSF.812.345

[17] G. Kerekes, M. Kocsisné Baán, I. Felde: Comparison of Bio-oils to Mineral Quenching Oils by their Heat Removal Capabilities, Production Processes and Systems, Vol. 7. (2014.) No. 1., pp. 113-124

[18] Felde I., Kerekes G., Mucsi A.: Edzőközegek korszerü vizsgálati módszerei, Miskolci Egyetem, 2015. ISBN 978-963-358-083-7, 94 p.

[19] Cserjésné Sutyák Á., Szilágyiné Bíró A.: Acélok edzhetőségének becslése kémiai összetétel alapján, GÉP 63 : 11 pp. 49-54. , 6 p. (2012.)

[20] Kocsisné Baán M., Rowshan R.: Lézeres felülettechnológiák kutatása a Mechanikai Technológiai Tanszéken, Gép, 62. k. (2011.) 4. sz. pp. 42-45.

[21] Szávai Sz., Bézi Z., Béres L., Szilágyiné Bíró A.: Cementált görgő felületi tulajdonságainak meghatározása numerikus modellezéssel élettartam elemzés céljából In: Barabás, István (szerk.) XXVII. Nemzetközi Gépészeti Konferencia: OGÉT 2019, Nagyvárad, Románia: Erdélyi Magyar Tudományos Társaság, (2019.) pp. 536-539., 4p.

[22] Kuzsella L., Lukács J., Szücs K.: Fizikai szimulációval végzett vizsgálatok S96QL jelü, nagyszilárdságú acélon, GÉP 63: 11 pp. 37-42., 6 p. (2012)

[23] Kuzsella L., Réger M.: Nagyszilárdságú acélok fázisátalakulásainak meghatározása fizikai szimuláció és matematikai modellezés segítségével, Proceedings, XXII. Nemzetközi Gépészeti Találkozó (OGÉT 2014), 2014. április 24-27, Nagyszeben, pp.213-216. 
[24] Tisza M., Kerekes G.: Számítógépes mérnöki módszerek alkalmazása a Mechanikai Technológiai Tanszék oktatási gyakorlatában, GÉP 63 : 11 pp. 73-78., 6 p. (2012.)

[25] Szilágyiné Biró A., Nagy D., Kocsisné Baán M.: A gáz és plazma közegü karbonitridálás összehasonlítása a kialakult rétegmélység szempontjából, In: Bitay, Enikő (szerk.) Fiatal Müszakiak Tudományos Ülésszaka (FMTÜ) XVIII. nemzetközi tudományos konferencia, Kolozsvár, 2013. március 21-22. Kolozsvár, Románia: Erdélyi Múzeum-Egyesület (EME), (2013) pp. 387-390. , 4 p.

[26] Marosné Berkes M., Szilágyiné Biró A., Lőrincz A., Koncsik Zs.: Műszerezett karcvizsgálat alkalmazása karbonitridált acélok felületi rétegének minősítő eljárásában, GÉP $66: 1$ pp. 28-35., 8 p. (2015.)

[27] Szilágyiné Bíró A., Bulla P., Szabó E.: Gáz és plazma karbonitridált rétegek GDOES profiljának összehasonlítása, In: Dr. Csibi, Vencel-József (szerk.) OGÉT 2013. XXI Nemzetközi Gépészeti Találkozó Kolozsvár, Románia: Erdélyi Magyar Müszaki Tudományos Társaság (EMT), (2013.), pp. 391-394., 4 p.

[28] Kuzsella L., Frigyik G., Marosné Berkes M.: Nitridált kéreg tribológiai jellemzésének lehetőségei pp. 55-60. In: Tóth, Tamás (szerk.) XXV. Hőkezelő és Anyagtudomány a Gépgyártásban Országos Konferencia és Szakkiállítás, Budapest, Gépipari Tudományos Egyesület, Hőkezelő Szakosztály, (2012.) p. 216

[29] A. S. Shiraz, A. Szilágyiné Bíró, M. Marosné Berkes: Investigation of the tribological performance of wear resistant surface layers produced on automotive tool steel by duplex heat treatments, In: Bodzás, Sándor; Mankovits, Tamás (szerk.) Proceedings of the 5th International Scientific Conference on Advances in Mechanical Engineering (ISCAME 2017), Debrecen, Magyarország, (2017.) pp. 472-478., 7 p.

[30] M. Kocsisné Baán: Modernisation of Engineering Education by the Network of HEIs for Automotive Industry, Conference about the status and future of the educational and R\&D services for the vehicle industry, Magyar Tudományos Akadémia, Budapest, 2014. január 31.

[31] Z. Kolozsváry, M. Kocsisné Baán: Effect of new developments in materials science on surface engineering and engineering education 7th International Materials Education Symposium, University of Cambridge, 9-10 April, 2015 